\title{
Effect of Integrated Weed Management on Growth, Yield, Yield Attributes and Economics of Grain Amaranth (Amaranthus hypochondriacus L.) under South Gujarat Condition
}

\author{
D.I. Chaudhari*, L.J. Desai and P.H. Kalal \\ Department of Agronomy, N. M. College of Agriculture, Navsari Agricultural University, \\ Navsari-396 450 (Gujarat), India \\ *Corresponding author
}

A B S T R A C T

Keywords

Grain amaranth, Weed management,

Economics,

Oxyfluorfen,

Oxadiargyl, Fenoxy

prop ethyl

Article Info

Accepted:

20 June 2019

Available Online:

10 July 2019
Field experiment was conducted on dark brown soil of the college farm, N. M. College of Agriculture, Navsari Agricultural University, Navsari during rabi season of 2016-2017 to study the effect of integrated weed management on growth, yield, yield attributes and economics of grain amaranth (Amaranthus hypochondriacus L.) Production potential, higher profit and effective weed control in grain amaranth can be achieved by maintaining weed free through hand weeding throughout crop growth period, where labours are easily available. In case of labours scarcity, application of oxyfluorfen $50 \mathrm{~g} / \mathrm{ha} \mathrm{PE}$ fb fenoxy prop ethyl $50 \mathrm{~g} / \mathrm{ha} \mathrm{PoE}$ at 40 DAS also equally effective.

\section{Introduction}

Amaranths is one of the few $\mathrm{C}_{4}$ crop species other than grasses. Amaranth is a quick growing multipurpose crop suitable for poor soils of semi-arid and seasonal wet areas. This crop is highly resistant to extreme stress conditions.

Grain amaranth (Amaranthus hypochondriacus $\mathrm{L}$.) is a potential upcoming subsidiary food crop, considered by many as crop of the future. Green leaf of amaranth is used as vegetable for human being and fodder for animals. The grains of this crop are used in quality human diet. Protein content in grains varies from 11-13\% and the quality of protein is equivalent to fish protein. It is observed that seeds of $A$. cruentus L. A. hypochondriacus L. contained higher crude protein $(16.86 \%)$, moisture $(11.88 \%)$, crude fat $(4.30 \%)$, crude fibre $(2.90 \%)$, ash $(2.10 \%)$, carbohydrates (63.13\%), calcium $(169.63 \mathrm{mg} / 100 \mathrm{~g})$, iron (10.42 mg/100 g), phosphorus (395.33 mg/100 g) (Munjal et al., 1999). Medicinal point of view the amaranth is also important. The tocopherol fraction of amaranth oil contains important cholesterol lowering agents, some 
of which could be useful in treating cardiovascular disease. Amaranth grain can be used as popcorn, making sweets, biscuits, pastry etc.

There are several factors responsible for retarding the production and productivity of grain amaranth. Among which, weed infestation is reported to cause yield losses. Yield losses due to weed competition vary considerably depending on the level of weed infestation and weed species prevailing. Nevertheless, almost all values reflect the seriousness of the weed problem.

Besides, weeds consume more labours, as well as increase the cost of production. However, recently the adopting of integrated weed management, inclusive application of herbicide and cultural practices has been found more effective in control of weeds (Arya, 2004).

\section{Materials and Methods}

An experiment was conducted on College Farm, Navsari Agricultural University, Navsari during rabi season of 2016-17. Twelve treatments comprising of weed management practices viz., $\mathrm{T}_{1}$ : Weed Free, $\mathrm{T}_{2}$ : One hand weeding at $20 \mathrm{DAS}, \mathrm{T}_{3}$ : Two hand weeding at 20 DAS and 40 DAS, T: Oxyfluorfen $50 \mathrm{~g} / \mathrm{ha} \mathrm{PE}, \mathrm{T}_{5}$ : Oxadiargyl 50 $\mathrm{g} / \mathrm{ha}$ PoE at 20 DAS, $\mathrm{T}_{6}$ : Fenoxy prop ethyl 50 $\mathrm{g} / \mathrm{ha}$ PoE at $20 \mathrm{DAS}, \mathrm{T}_{7}$ : Oxyfluorfen $50 \mathrm{~g} / \mathrm{ha}$ PE $f b$ Oxadiargyl $50 \mathrm{~g} / \mathrm{ha}$ PoE at $40 \mathrm{DAS}, \mathrm{T}_{8}$ : Oxyfluorfen $50 \mathrm{~g} / \mathrm{ha}$ PE $f b$ Fenoxy prop ethyl $50 \mathrm{~g} / \mathrm{ha} \mathrm{PoE}$ at $40 \mathrm{DAS}, \mathrm{T}_{9}$ : Oxyfluorfen $50 \mathrm{~g} / \mathrm{ha} \mathrm{PE}+$ One hand weeding at $40 \mathrm{DAS}$, $\mathrm{T}_{10}$ : Oxadiargyl $50 \mathrm{~g} / \mathrm{ha}$ PoE, $20 \mathrm{DAS}+$ One hand weeding at $40 \mathrm{DAS}, \mathrm{T}_{11}$ : Fenoxy prop ethyl $50 \mathrm{~g} / \mathrm{ha}$ PoE, 20 DAS + One hand weeding at $40 \mathrm{DAS}, \mathrm{T}_{12}$ : Weedy check; were evaluated in randomized block design with three replications. The soil of the experimental field was clayey in texture, low in available nitrogen $(191 \mathrm{~kg} / \mathrm{ha})$ and medium in available phosphorus $(32 \mathrm{~kg} / \mathrm{ha})$, fairly rich in available potash (358 kg/ha), slightly alkaline in reaction $(\mathrm{pH}$ 7.9) and having well drainage with good moisture retention capacity. The Grain amaranth cv. G A 2 was sown on $21^{\text {st }}$ November, 2016 and harvested on $29^{\text {nd }}$ February 2017.

The crop was fertilized with $60 \mathrm{~kg} \mathrm{~N}$ and 40 $\mathrm{kg} \mathrm{P}_{2} \mathrm{O}_{5} /$ ha. Observation regarding to the growth parameters i.e. plant height $(\mathrm{cm})$ at 30 DAS, 60 DAS and at harvest, Length of main inflorescence $(\mathrm{cm})$, Number of lateral spikelets per spike. Observation regarding to yield and yield attributes i.e. test weight $(\mathrm{g} / \mathrm{cc})$, grain and stover yield $(\mathrm{kg} / \mathrm{ha})$ and harvest index. The data were analyzed procedures described by Panse and Sukhatme (1985).

\section{Results and Discussion}

Effect of weed management on growth parameters

It is evident from the data presented in (Table 1) that the initial as well as at harvest plant population was not influenced significantly by various weed management treatments. Further, the results indicated that there was no adverse effect on germination and establishment of grain amaranth crop due to pre and post emergence application of herbicides during the course of investigation.

Data shows that the significantly higher plant height $(68.6$ and $183.3 \mathrm{~cm})$ was observed under $\mathrm{T}_{1}$ (weed free) which was statistically at par with treatment $T_{8}, T_{3}, T_{7}$ and $T_{10}$ at 60 DAS and at harvest, respectively and At 30 DAS, plant height fails to reach at significantly level due to different weed management treatment. The significantly lower plant height $(53.1$ and $154.4 \mathrm{~cm})$ was recorded under $\mathrm{T}_{12}$ (weedy check) at $60 \mathrm{DAS}$ 
and at harvest, respectively. The increase in plant height at periodical growth stage under weed free condition during critical crop competition period might be due to effective control of weeds under these treatments, which improved growth of crop and checked nutrients drain by weeds.

The shortest plant height might be due to severe competition by weeds for moisture and nutrients; consequently, the plant growth was affected. Significant improvement in growth characters also might be due to increase water and nutrient uptake, which might have accelerated photosynthetic rate, thereby increasing the supply of carbohydrates, resulted in increased cell division, multiplication and elongation leading to increase the higher plant growth.

Treatment $\mathrm{T}_{1}$ (weed free) proved better than other herbicides as well as weedy check. Suppressed weed allowed more light, moisture, nutrients and space to crop plant, which resulted in better growth characters. Similar results were also reported by Singh et al., (2017) and by David (1997)

\section{Effect on yield and yield attributes}

The entire yield attributes namely Length of main inflorescence $(\mathrm{cm})$, number of lateral spikelets per spike, grain yield $(\mathrm{kg} / \mathrm{ha})$, stover yield (kg/ha), harvest index (\%) and test weight showed significant response to weed management practices but harvest index (\%) (Table 2). The significantly longer main inflorescence $(84.28 \mathrm{~cm})$ was recorded in treatment $\mathrm{T}_{1}$ (weed free) which was statistically at par with treatment $\mathrm{T}_{8}, \mathrm{~T}_{3}, \mathrm{~T}_{7}$, $\mathrm{T}_{10}, \mathrm{~T}_{6}$, and $\mathrm{T}_{11}$ at harvest. The weed control treatments failed to exert its significant effect on Number of lateral spikelets per spike and harvest index. The higher test weight value $(0.90 \mathrm{~g} / \mathrm{cc})$ observed under treatment $\mathrm{T}_{1}$ (weed free) which was statistically at par with treatment $\mathrm{T}_{8}, \quad \mathrm{~T}_{3}$ and $\mathrm{T}_{7}$. Numerically maximum number of lateral spikelets per spike and harvest index was observed under weed free treatment while minimum in weedy check treatment. The higher grain and stover yield (1296 and $3156 \mathrm{~kg} / \mathrm{ha}$ ) was recorded under the weed free treatment $\left(\mathrm{T}_{1}\right)$.

The treatment $T_{8}$ in which pre emergence application of Oxyfluorfen $50 \mathrm{~g} / \mathrm{ha} f b$ post emergence application of Fenoxy prop ethyl $50 \mathrm{~g} / \mathrm{ha}$ at $40 \mathrm{DAS}$ was at par with $\mathrm{T}_{3}, \mathrm{~T}_{9}$, and $\mathrm{T}_{11}$. The magnitude of increase in grain yield under treatment $\mathrm{T}_{1}$ was to the tune of $57.09 \%$ over weedy check $\left(\mathrm{T}_{12}\right)$, while $54.69 \%$ in $\mathrm{T}_{8}$, $50.40 \%$ in $\mathrm{T}_{3}$ and $45.05 \%$ increase in $\mathrm{T}_{11}$ over weedy check. The per cent increase in stover yield due to weed free condition $\left(\mathrm{T}_{1}\right)$ was to the tune of $54.24 \%$ over weedy check $\left(\mathrm{T}_{12}\right)$, while $52.84 \%$ increase in $\mathrm{T}_{8}, 49.80 \%$ increase in $\mathrm{T}_{3}, 43.76 \%$ increasing in $\mathrm{T}_{9}$ and $42.49 \%$ increase in $\mathrm{T}_{11}$ over unweeded treatment $\left(\mathrm{T}_{12}\right)$.

The reason for the increase in grain yield was mainly due to weed free condition provided at critical crop weed competition period, which might be due to effective control of weeds under these treatments. Grain yield is primarily a function of accumulation of photosynthates resulted in growth and increase yield attributes. Therefore, it can be inferred that significant improvement in these parameters contributed towards higher grain yield. The yield loss study also shows that reduced weed population initially by preemergence herbicide followed by weed control around 25 to 30 DAS either by post emergence herbicide or hand weeding has less reduction in yield. This result indicated that appreciable increase in grain and stover yield could be the significant improvement in plant growth in terms of plant height under those treatments. Similar effect was also reported by Patel et al., (2012), Shukla et al., (2014) Gaharwar et al., (2017). 
Table.1 Effect of weed management on growth parameters of grain amaranth

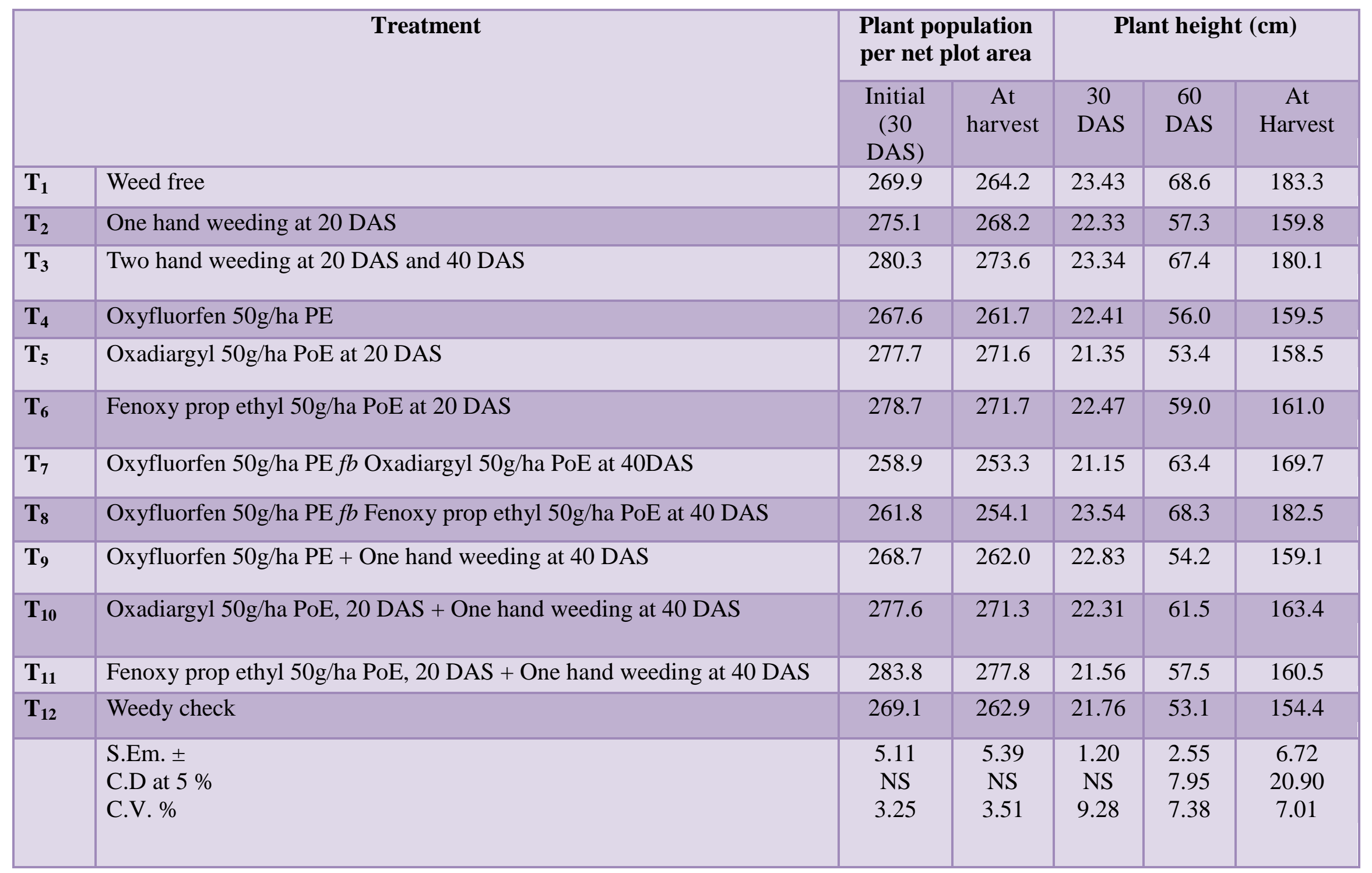


Table.2 Effect of weed management on yield parameters and economics of grain amaranth

\begin{tabular}{|c|c|c|c|c|c|c|c|c|}
\hline \multicolumn{2}{|r|}{ Treatment } & \multirow{3}{*}{$\begin{array}{c}\text { Test } \\
\text { weight } \\
\text { (g/cc) }\end{array}$} & \multicolumn{2}{|c|}{ Yield(kg/ha) } & \multirow{2}{*}{$\begin{array}{c}\text { Cost of } \\
\text { cultivatio } \\
\text { n } \\
(₹ / h a)\end{array}$} & \multirow{2}{*}{$\begin{array}{l}\text { Gross } \\
\text { returns } \\
\text { (₹/ha) }\end{array}$} & \multirow{2}{*}{$\begin{array}{c}\text { Net } \\
\text { returns } \\
\text { (₹/ha) }\end{array}$} & \multirow{2}{*}{$\begin{array}{c}\text { B:C } \\
\text { Rati } \\
\text { o }\end{array}$} \\
\hline & & & Grain & Stover & & & & \\
\hline $\mathbf{T}_{1}$ & Weed free & & 1296 & 3156 & 17784 & 78409 & 60625 & 3.40 \\
\hline $\mathbf{T}_{2}$ & One hand weeding at 20 DAS & 0.71 & 874 & 2269 & 16360 & 52898 & 36538 & 2.23 \\
\hline $\mathbf{T}_{\mathbf{3}}$ & Two hand weeding at 20 DAS and 40 DAS & 0.87 & 1121 & 2877 & 17072 & 67834 & 50762 & 2.97 \\
\hline $\mathbf{T}_{4}$ & Oxyfluorfen 50g/ha PE & 0.66 & 919 & 2412 & 14996 & 55593 & 40597 & 2.70 \\
\hline $\mathbf{T}_{5}$ & Oxadiargyl 50g/ha PoE at 20 DAS & 0.62 & 849 & 2111 & 14593 & 51385 & 36792 & 2.52 \\
\hline $\mathbf{T}_{6}$ & Fenoxy prop ethyl $50 \mathrm{~g} / \mathrm{ha} \mathrm{PoE}$ at $20 \mathrm{DAS}$ & 0.75 & 973 & 2459 & 15549 & 58862 & 43313 & 2.78 \\
\hline $\mathbf{T}_{7}$ & Oxyfluorfen 50g/ha PE $f b$ Oxadiargyl 50g/ha PoE at 40DAS & 0.85 & 825 & 2072 & 15115 & 49895 & 34780 & 2.30 \\
\hline $\mathbf{T}_{8}$ & $\begin{array}{l}\text { Oxyfluorfen } 50 \mathrm{~g} / \mathrm{ha} \text { PE } f b \text { Fenoxy prop ethyl } 50 \mathrm{~g} / \mathrm{ha} \text { PoE at } 40 \\
\text { DAS }\end{array}$ & 0.88 & 1227 & 3062 & 16071 & 74242 & 58171 & 3.61 \\
\hline $\mathbf{T}_{9}$ & Oxyfluorfen 50g/ha PE + One hand weeding at 40 DAS & 0.63 & 1048 & 2568 & 17132 & 63403 & 46271 & 2.70 \\
\hline $\mathbf{T}_{10}$ & $\begin{array}{l}\text { Oxadiargyl 50g/ha PoE, } 20 \text { DAS + One hand weeding at } 40 \\
\text { DAS }\end{array}$ & 0.78 & 862 & 2185 & 16729 & 52141 & 35412 & 2.11 \\
\hline $\mathbf{T}_{11}$ & $\begin{array}{l}\text { Fenoxy prop ethyl } 50 \mathrm{~g} / \mathrm{ha} \text { PoE, } 20 \mathrm{DAS}+\text { One hand weeding } \\
\text { at } 40 \text { DAS }\end{array}$ & 0.75 & 1012 & 2511 & 17685 & 61243 & 43558 & 2.46 \\
\hline $\mathbf{T}_{12}$ & Weedy check & 0.59 & 556 & 1444 & 14224 & 33964 & 19740 & 1.38 \\
\hline & $\begin{array}{l}\text { S.Em. } \pm \\
\text { C.D at } 5 \% \\
\text { C.V. } \%\end{array}$ & $\begin{array}{l}0.03 \\
0.08 \\
6.21\end{array}$ & $\begin{array}{c}69.61 \\
217 \\
12.51\end{array}$ & $\begin{array}{c}154.74 \\
482 \\
11.04\end{array}$ & - & - & - & - \\
\hline
\end{tabular}

Sale price of grain amaranth 1. Grain - ₹ $60 / \mathrm{kg} 2$. Stover - ₹ $0.20 / \mathrm{kg}$ 


\section{Economics}

Economics is the major consideration of farmers, while taking a decision regarding the adoption of the recently developed new technology. Hence the gross realization, net realization and benefit cost ratio were computed for different weed management treatments. Data presented in (Table 2) revealed that maximum gross returns and net return of (₹78409/ha and ₹60625/ha) was realized under the treatment $\mathrm{T}_{1}$ (weed free), followed by treatment $\mathrm{T}_{8}$ (₹ 74242/ha and ₹58171/ha) and $\mathrm{T}_{3}$ (₹67834/ha and ₹50762/ha). The higher grain yields recorded under these treatments might be responsible for higher gross return. However, the maximum B: $\mathrm{C}$ ratio (3.61) was accrued under the treatment $T_{8}$ followed by $T_{1}$. The lowest gross return, net return and $\mathrm{B}$ : $\mathrm{C}$ was accrued under the treatment $\mathrm{T}_{12}$ ( ( $33964 / \mathrm{ha}$, ₹19740/ha and 1.38 respectively). So higher gross returns along with the lowest cost under $\mathrm{T}_{1}, \mathrm{~T}_{8}, \mathrm{~T}_{3}$ treatments might be responsible for higher net return and $\mathrm{B}$ : $\mathrm{C}$ ratio. These findings are in close vicinity with those reported by Patel et al., (2012), Shukla et al., (2014), Gaharwar et al., (2017).

Based on results of the field experiment, it seems quite logical to conclude that production potential, higher profit and effective weed control in grain amaranth can be achieved by maintaining weed free through hand weeding throughout crop growth period, where labours are easily available. In case of labour scarcity, application of oxyfluorfen $50 \mathrm{~g} / \mathrm{ha} \mathrm{PE} f b$ fenoxy prop ethyl $50 \mathrm{~g} / \mathrm{ha} \mathrm{PoE}$ at 40 DAS, also equally effective.

\section{References}

Arya, R.L. 2004. Integrated wed management in chickpea (Cicer arientnum) + mustard (Brassica juncea) intercropping system under rainfed conditions. Indian Journal of Agronomy, 49(2): 98-100.

David, O. Ojo. 1997. Effect of weeding frequencies on grain amaranth (Amaranthus cruentus L.) growth and yield. Elsevier Science Ltd., 5(16): 463466.

Donald, C. M. 1963. Copetition among crop and plants. Advance Agronomy, 15(1): 114.

Gaharwar, A. M., Patil, N. and Ughade, J. D. (2017). Effect of integrated weed management on growth, yield and economic returns on onion (Allicum cepa L.). Asian Journal of Horticulture, 12(2): 193-197.

Munjal, S. V., Mahayan, P. N., Patil Y. M. And Patil, S. R. 1999. Evaluation of grain amaranth cultivar for biochemical and mineral constituents. Journal Maharashtra Agricultural University, 24(1): 58-60.

Panse, V. G. and Sukhatme, P.V. 1967. Statistical Method for Agricultural Workers. ICAR, New Delhi.

Patel, T. U., Patel, C. L., Patel, D. D., Thanki, J. D., Arvadia, M. K. and Vaidya, H. B. 2012. Performance of onion under weed and fertilizer management. Indian Journal of Weed Science, 44(3): 152158.

Shukla, D. K., Prasad, B. And Pratap, T. 2014. Weed management strategies for better yield and economics of grain amaranth (Amaranthus hypochondricus) in mountain agriculture. Journal of Hill Agriculture, 5(2): 194-197.

Singh, M. C., Phogat, B. S. and Raigar, H. L. 2017. Effect of different weed control practices on grain amaranth (Amaranthus hypochondriacus L.). International Journal of Science, Environment and Technology, 6(1): 849-853. 


\section{How to cite this article:}

Chaudhari, D.I., L.J. Desai and Kalal, P.H. 2019. Effect of Integrated Weed Management on Growth, Yield, Yield Attributes and Economics of Grain Amaranth (Amaranthus hypochondriacus L.) under South Gujarat Condition. Int.J.Curr.Microbiol.App.Sci. 8(07): 2598-2604. doi: https://doi.org/10.20546/ijcmas.2019.807.320 